\title{
SCHISTOSOMIASIS MANSONI IN THE MUNICIPALITY OF PEDRO DE TOLEDO (SÃO PAULO, BRAZIL) WHERE THE Biomphalaria tenagophila IS THE SNAIL HOST. I - PREVALENCE IN HUMAN POPULATION (1)
}

\author{
L. C. S. DIAS (2), U. KAWAZOE (2), C. GLASSER (3), S. HOSHINO-SHIMUUU (4), H. Y. KANAMURA (4), \\ J. A. CORDEIRO (2). O. F. GIARITA (3) \& G. J. ISHIIATA 3 (
}

\begin{abstract}
SUMMARY
Due to the scarce information about the epidemiological features of schistoso miasis in which the vector is Biomphalaria tenagophila, an investigation was carried in Pedro de Toledo in 1980 where such peculiarity is observed. Stool examinations (Kato Katz method) were performed in 4.741 individuals $(22.8 \%$ positive to Schistosoma mansoni eggs) of this 583 had previously received chemoterapy and 4,158 remainders, untreated. The schistosomiasis prevalence in those two groups where respectively $31.7 \%$ and $21.6 \%$. Epidemiological investigation showed that $83.6 \%$ were autochthonous cases from the studied area: the autochthonous prevalence rate, and the intensity of infection in the untreated autochthonous cases were higher in males than in females; the intensity in the latter untreated group was low, $58.5 \mathrm{eggs} / \mathrm{g}$ feces (geometric mean). Moreover, according to the age groups the intensity of infections correlated well $\left(r_{s}=0.745\right)$ with the prevalence rates. Schistosomiasis was veri fied to occur mostly during the leisure time and by the use of water streams for housework in rural zone. Only $0.4 \%$ out of 1,137 snails was positive for $\mathbf{S}$. mansoni cercariae, apparently unchanged from the 1978 study when the human prevalence was $12.0 \%$. The studied area presented differences and similarities in relation to the other Brazilian areas were the main intermediate host is B. glabrata.
\end{abstract}

KEY WORDS: Schistosoma mansoni; Biomphalaria tenagophila; Epidemiology.

\section{INTRODUCTION}

In the Valley of Ribeira (State of São Paulo - Brazil), the human schistosomiasis was first recorded in $1953^{21}$, with 43 autochthonous cases in the District of Ana Dias, Municipality of Ita riri, neighboring the Municipality of Pedro de Toledo, where the present study was performed. Since that time only Biomphalaria tenagophila has been found in the molluscan breeding sites but, those snails were already positive for Schistosoma mansoni cercariae in about $1.7 \%$. In the Municipality of Pedro de Toledo, autoch thonous cases of schistosomiasis were also detected as reported by PIZA \& RAMOS $^{21}$, however, in only 6 of the studied population.

(1) Supported by SUCEN, FAPESP and CNPq.

(2) Professor of Universidade Estadual de Campinas. Inst. Biologia. Depto. Parasitologia, C. P. 6109. CEP 13081 Campinas, SP. Brazil

(3) Epidemiologist of Superintendencia de Controle de Endemias. Sáo Paulo, SP Brasil

(4) Professor of Universidade de Sào Paulo. Sào Paulo, SP. Brazil. 
DIAS. L. C. S.; KAWAZOE, U: GLASSER, C.: HOSHINO SHIMIZT . S : KANAMURA. H. Y.: CORDEIRO. J. A.: GUA RITA. O. F. \& ISHIHATA. G. I. - Schistosomiasis mansoni in the municipality of Pedro de Toledo isao Paulo Brazil where the Biomphalaria tenagophila is the snail host. I - Prevalence in human population. Rev. Inst. Med. trop. Sáo Paulo, 31 12) $110118,1989$.

More recently (1970), the Superintendency of Endemic Disease Control (SUCEN I of the Sào Paulo State Health Department has established a Schistosomiasis Mansoni Control Programme in that area. This programme includes yearly stool examination for all the population exposed to the risk of transmission, chemoterapy of infected individuals, periodical snails examinations from the water collection, health education, and. application of molluscicide drugs in the streams whenever infected snails with cercariae of $\mathbf{S}$. mansoni are found.

Despite this effort the prevalence has increased from $4.0 \%(1970$ ) to $12.0 \%$ (1978); of the latter percentage $85.0 \%$ consisted of autochthonous cases. The rate of infected $B$. tenagophila howe. ver seemed unchanged since 1970 , with $1.0 \%$.

The present study was undertaken due to that increasing rate of schistosomiasis mansoni verified in Pedro de Toledo and also because of the lack of studies in relation to the natural history of schistosomiasis in regions where $\mathbf{B}$. tenagophila is the intermediate host. The whole project which started in 1980 includes a detailed investigation on parasitologicai an epidemiological aspects of urban and rural areas during. a period of approximately 8 years. These studies will be performed as following: prevalence of the infection in the human population and in the small mammals; prevalence of snail infection with S. mansoni; evaluation of parasitological and immunological methods for diagnosis of schistosomiasis; clinical study of infected indivi duals; specific treatment and assessment of pa rasitologic cure of treated patients: application of molluscicide drugs in all natural snail bree ding sites, whenever infected molluscs are detec ted; evaluation of transmission by the incidence of schistosomiasis using control groups; use of sentinel-mice; infection rate and density of the snail host.

In this paper, part of the epidemiological stu dies concerning the prevalence of urban and ru ral schistosomiasis, identification of autoch tho nous cases and assessment of previously treated subjects will be reported.

\section{MATERIAL AND METHODS}

\section{Description of the studied area}

Pedro de Toledo is located in the Valley of Ribeira. near the Southern coast of Sāo Paulo State. Brazil. The studied region comprises an area of $631 \mathrm{~km}^{2}$ and the town is located $43.5 \mathrm{~m}$ above sea level. The landscape is hilly with many small streams which are shallow with many stones on its margin and plentiful vegetation. The Itariri River is the main stream and belongs to the Ribeira de Iguape basin. The climate accor ding to Kopenn's classification can be conside red as tropical and humid. The mean tempera ture is about $22^{\circ} \mathrm{C}$ in the hottest month whereas, in the coldest month, $18^{\circ} \mathrm{C}$. In the dryest month the rainfall is about $60 \mathrm{~mm}$, however, in January and February the rainfall is heavier reaching 203 to $220 \mathrm{~mm}$. According to the 1980 census of the Brazilian Institute of Geography and Statistics, Pedro de Toledo has 6,076 inhabitants, with 2,336 living in the urban zone and 3.704 in the rural zone. The majority of the people is white. The main local activity is agriculture, mostly in banana plantation. According to SUCEN, about 5.000 inhabitants live either in places where the transmission of schistosomiasis has ocurred or is presently occuring. These areas are called $F()$ CI. The remaining 1,000 inhabitants live in pla ces where this parasitosis has not been reported yet.

The studied population from the FOCI was 2,370 inhabitants from the urban zone and 2,371 from the rural zone. The urban inhabitants lived in a small town with the following facilites: tap water and power supplies, around $85.0 \%$ of the dwellings had sewer system, and $50.0 \%$ of the streets were paved: the sewage was treated. The' rural inhabitants, generally, lived in poor houses scattered along non-paved roads in 15 areas na mely: Rio do Peixe, Rio do Peixe I, km 106, km 110, Fazenda São José, Braço do Meio, Braço do Meio I, Mariano, Mariano I, Ribeirão do Luiz, Três Barras, Água Parada, Jardim Caju, Água Fria and Vila Batista. There were no irrigation canals in the area; there were drain channels and small streams in the banana plantation Which were the main breeding places of B. tenagophila; there was no sewers system available. 
DIAS, L C. S.; KAWAZOE. U.: GLASSER, C.; HOSHINO-SHIMIZU, S.; KANAMURA, H. Y .: CORDEIRO, J, A.: GUA RITA, O. F. \& ISIIfIATA. G. J. - Schistosomiasis mansoni in the municipality of Pedro de Toledo iSáo Paulo, Brazil) where the Biomphalaria tenagophila is the snail host. I - Prevalence in human population. Rev. Inst. Med. trop. São Paulo, 31 (2): 110-118, 1989.

\section{Laboratory method for diagnosis}

Stool examination was carried out in 1980 according to Kato-Katz quantitative method ${ }^{11}$, by collecting one fecal sample from each indivi. dual and preparing three stides for searching eggs of S. mansoni and of other non-related helminths.

\section{Statistical analysis}

Results of laboratory test and personal data regarding to sex, age, skin color, occupation, places of birth, living sites, epidemiological classification, as well as, previous chemotherapy were transcribed into individual computer cards.

The intensity of infection was expressed as geometric mean of number of excreted eggs per gram feces, due to the irregular distribution of $\operatorname{eggs} s^{15}$.

The following methods were used for the statistical analyses: analyses of variance (ANOVA), Tukey's test for contrasts, Kolmogorov-Smirnov goodness-of-fit test and confidence intervals. The level of $5.0 \%(\mathrm{p}<0.05)$ was adopted as minimum significant difference for rejecting the null hypothesis. Sperman correlation coefficients were estimated $^{25}$ to verify the correlation between the intensity of the infection observed in different age groups or localities and the prevalence of schistosomiasis.

\section{RESULTS}

A total of 4,741 subjects could be studied (Table 1) and the overall schistosomiasis mansoni prevalence in Pedro de Toledo was $22.8 \%$ (1083/4741). The rural zone presented higher infection rate $(25.6 \%)$ in relation to the urban area $(20.2 \%)$ but no significant at the $5.0 \%$ level. This parasitosis also prevailed in rural even after the separation into two sub-groups, one that received treatment and other, no-treatment (Table $1)$.

The prevalence rates verified in rural untreated population to schistosomiasis varied greately according to the locality: $5.9 \%$ (Rio do Peixe I), $14.5 \%(\mathrm{Km} \mathrm{110}), 17.8 \%(\mathrm{Km} \mathrm{106}), 20.9 \%$ (Rio do Peixe), $25.0 \%$ (Fazenda Sào José), $25.5 \%$ (Bra. ço do Meio I), 27.5\% (Mariano I), 30.2\% (Braço do Meio), 31.4\% (Ribeirão do Luiz), 31.6\% (Mariano), 31.9\% (Três Barras), $36.9 \%$ (Água Parada), $42.9 \%$ (Jardim Caju), 43.6\% (Água Fria) and $61.2 \%$ (Vila Batista).

In respect to 4,158 individuals without any previous treatment to $\mathbf{S}$. mansoni, the prevalen

TABLE 1

Prevalence of schistosomiasis mansoni in urban and rural areas of the municipality of Pedro de Toledo (Sāo Paulo State - Brazil - 1980) by parasitological Kato-Katz method, according to the treatment to the disease.

\begin{tabular}{|c|c|c|c|c|c|c|}
\hline \multirow{2}{*}{$\begin{array}{l}\text { Stool } \\
\text { Exarnination }\end{array}$} & \multicolumn{2}{|c|}{ Treatment } & \multicolumn{3}{|c|}{ Untreated } & \multirow{2}{*}{ Total } \\
\hline & $\begin{array}{c}\text { Urban } \\
\text { Area } \\
\%\end{array}$ & $\begin{array}{c}\text { Rural } \\
\text { Area } \\
\mathscr{c} /\end{array}$ & & $\begin{array}{c}\text { Urban } \\
\underset{\%}{\text { Area }}\end{array}$ & $\begin{array}{c}\text { Rural } \\
\text { Area } \\
\%\end{array}$ & \\
\hline Positive & $\begin{array}{c}26.4^{*} \\
( \pm 4.4)\end{array}$ & $\begin{array}{c}41.6 \\
( \pm 6.7)\end{array}$ & 185 & $\begin{array}{c}18.9 \\
( \pm 2.1)\end{array}$ & $\begin{array}{c}24.1 \\
( \pm 1.8)\end{array}$ & 898 \\
\hline Negative & $\begin{array}{c}73.2 \\
( \pm 4.4)\end{array}$ & $\begin{array}{c}58.4 \\
( \pm 6.7)\end{array}$ & 398 & $\begin{array}{c}81.1 \\
( \pm 2.1)\end{array}$ & $\begin{array}{c}75.9 \\
( \pm 1.8)\end{array}$ & 3,260 \\
\hline Total & 385 & 198 & 583 & 1,985 & 2,173 & 4,158 \\
\hline
\end{tabular}

* Confidence interval $95 \%$ 
DIAS, L. C. S.; KAWAZOE. U.; GLASSER, C.; HOSHINO-SHIMIZU, S.; KANAMURA, H. Y.; CORDEIRO, J. A.; GUA RITA, O. F. \& ISHIHATA, G. J. - Schistosomiasis mansoni in the municipality of Pedro de Toledo (Sāo Paulo, Brazil) where the Biomphalaria tenagophila is the snail host. I $\rightarrow$ Prevalence in human population. Rev. Inst. Med. trop. São Paulo, 31 (2): 110-118, 1989.

ce rates of helminthiasis were: Trichuris trichiura, $42.3 \%$, Ascaris lumbricoides, $40.4 \%$ and $\mathbf{S}$. mansoni, $21.6 \%$. There also were one case of infection with Enterobius vermicularis and one with Taenia sp.. Multiple parasitism with two or more species was observed in $36.4 \%$ of the cases.

Epidemiological investigation was possible to be done in $884(81.6 \%)$ out of 1083 carriers of S. mansoni, of these $83.6 \%$ (739) were autochthonous cases in Pedro de Toledo, $3.8 \%$ from other municipalities of Sāo Paulo State, $1.3 \%$ from other Brazilian States and $11.2 \%$ undetermined. Thus, the number of individuals acquired schistosomiasis only in São Paulo State was 772 $(87.3 \%)$.

All the statistical analyses were performed in untreated population or in autochthonous ca ses.

The analysis of variance could not be done in the total examined inhabitants $(4,741)$ becau se the full information (sex, age, domicile and epidemiological classification) were not obtained; from 3,407 residents with complete informations for this analysis was performed.
The ANOVA test indicate differences bet ween the prevalence of autochthonous schistosomiasis in 1,765 males ( $28.1 \%$ ) and in 1,642 females $(14.7 \%)$, as well as, among age groups comprising from 0 to over 60 years (Figure 1 and Table 2 ).

TABLE 2

Results obtained by the statistical analysis of variance (scale: arc sen $\sqrt{p}$ from data of Figure 1 , corresponding to the preva lence of S. mansoni infection determined by parasitological method (Kato Katz) according to the age groups, sex and zone, in the population of Pedro de Toledo, Sảo Paulo state, Brazil ( 1980 ).

\begin{tabular}{|c|c|c|c|c|}
\hline \multirow{3}{*}{ VARIANCE } & \multicolumn{4}{|c|}{ AGEGROUP } \\
\hline & \multicolumn{2}{|c|}{0 to over 60 years } & \multicolumn{2}{|c|}{5 to 29 years } \\
\hline & $\begin{array}{l}\text { Degree of } \\
\text { freedom }\end{array}$ & $\mathrm{F}$ & $\begin{array}{c}\text { Degree of } \\
\text { freedom }\end{array}$ & $\mathrm{F}$ \\
\hline Zone & 1 & 2.92 & 1 & 1.53 \\
\hline Sex & 1 & $41.09^{*}$ & 1 & $6.73^{\circ}$ \\
\hline Age group & 12 & 7.71 & 4 & 9.49 \\
\hline Zone $x$ Sex & 1 & 0.13 & 1 & 5.89 \\
\hline Zone $\mathrm{x}$ Age group & 12 & 1.42 & 4 & 1.08 \\
\hline Sex $\times$ Age group & 12 & 0.76 & 4 & 2.85 \\
\hline
\end{tabular}

Significance at the $5.0 \%$ level

In Figures 1 and 2, higher prevalence rates and intensity of infection can respectively be seen within the age groups from 5 to 29 years.

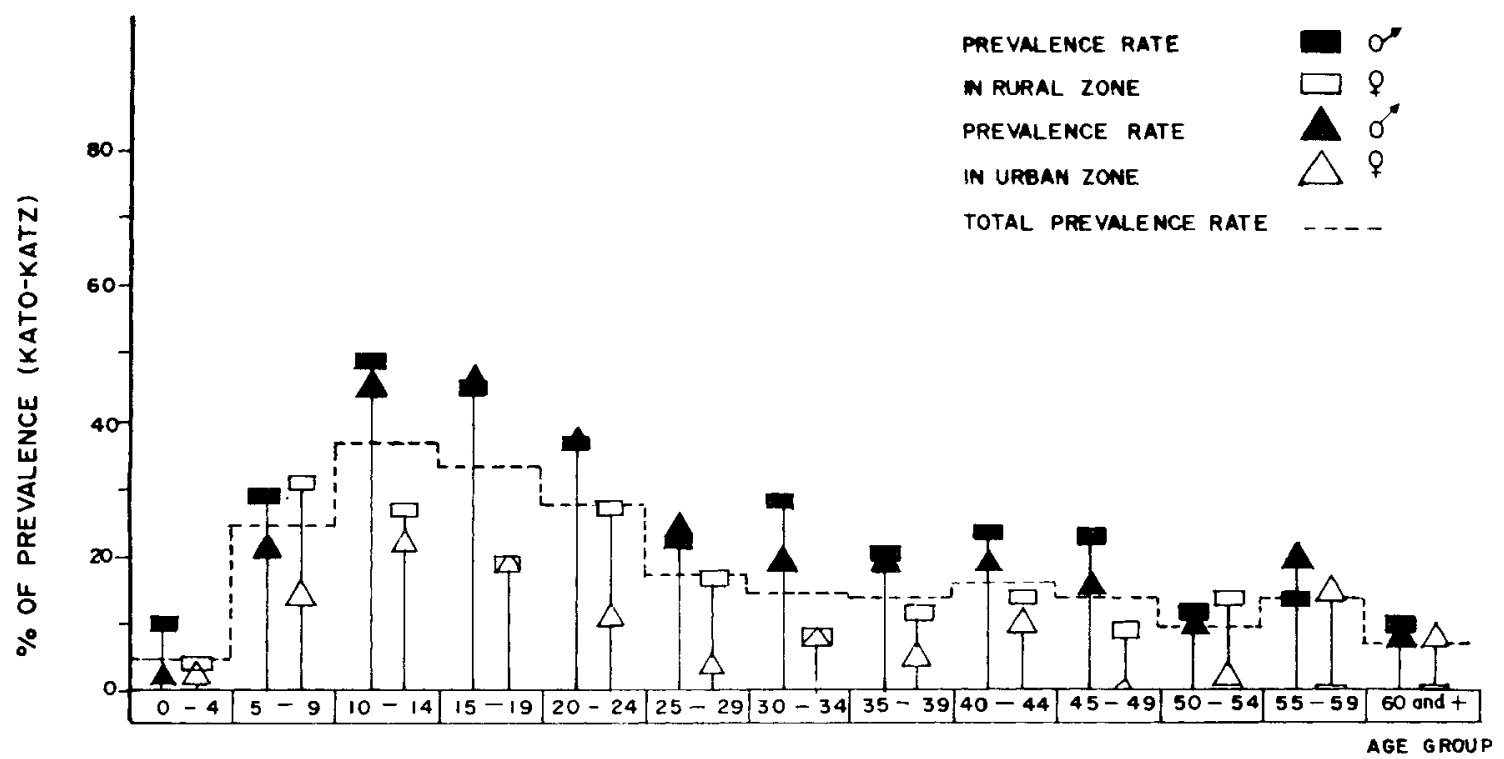

Fig. 1 - Prevalence rates of autochthonous schistosomiasis mansoni by the Kato.Katz method, according to age group sex. rural and urban zones, in Pedro de Toledo, Sào Paulo, Brazil (1980). 
DIAS. L. C. S.: KAWAZOE. U.: GLASSER, C.: HOSHINO SHIMIZU, S.: KANAMURA, H. Y.: CORDEIRO, J. A.: GUA RITA. O. F. \& ISIIHATA. G. J. - Schistosomiasis mansoni in the municipality of Pedro de Toledo isào Paulo. Brazil where the Biomphalaria tenagophila is the snail host. I - Prevalence in human population. Rev. Inst. Med. trop. São Paulo, 31 (2): 110-118, 1989

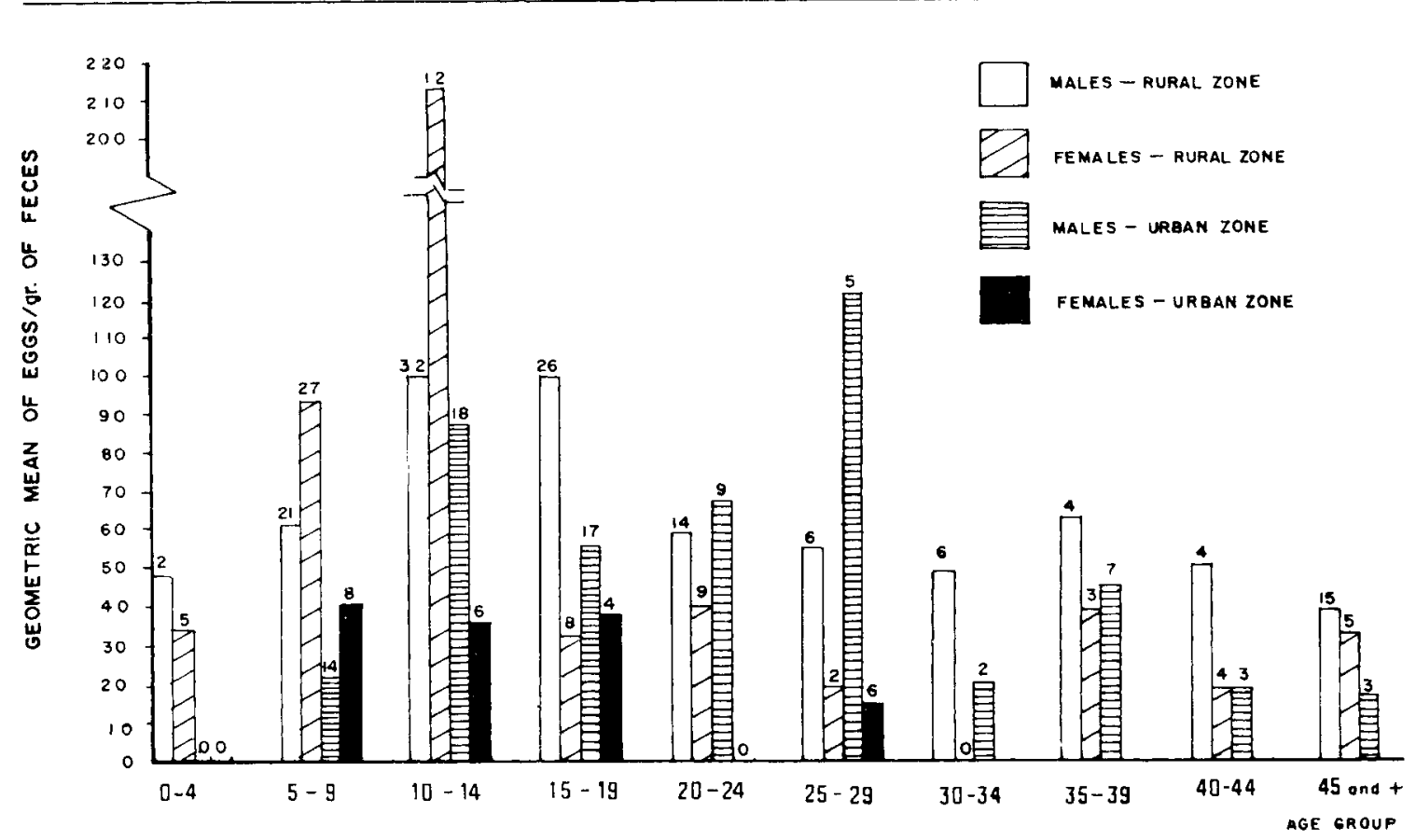

Fig, 2 -... Geometric mean of the number of $\mathbf{S}$. mansoni eggs per gram of feces by the Kato-Katz method. in 307 autoch thonous non treated individuals from Pedro de Toledo. Sao Paulo. Brasil 41980)

Obs. The 25 to 29 female age group in the urban zone also includes individuals from subsequent groups. Numbers placed above the columns indicate the number of sub jects examined.

ANOVA was also applied for these age groups and the results obtained ('Table 2 ) were similar to the afore mentioned study for all age groups, besides the significant difference verified in the interaction between zone and sex. More detailed studies done using Tukey's test showed that, in general, the age groups 10-14, 15-19 and 2024 had significantly higher prevalence rates than the remainder age groups. However, these three groups did not differ among them. The age group 5. 9 had significantly higher prevalence than the 0-4 and those more than 45 years of age and lower than the age group 10-14 (Tukey's test difference $5 \%=7.308 ; \mathrm{k}=11$ and $\mathrm{v}=7.1$.

The intensity of infection in 307 untreated autochthonous cases was 58.5 eggs'g feces (geo metric mean). The confidence intervals test sho wed statistically significant diference ( $p$ value less than 0.01 ) for the following conditions: in the rural zone the intensity of infection 166.7 eggs/g) was higher than in the urban area 144.6 eggs/g): the males presented higher infection (61.8 eggs/g) than females (53.3 eggs/g), while the males from the rural area had the egg excretion rate $(69.9 \mathrm{eggs} / \mathrm{g})$ higher than those from urban area $(49.8 \mathrm{eggs} / \mathrm{g})$; the males from the rural zone also eliminated more eggs $(61.4 \mathrm{eggs} / \mathrm{g})$ than those from urban zone $(32.1 \mathrm{eggs} / \mathrm{g})$.

The data which provided Figure 2 were analy sed by Kolmogorov Smirnov test and it was ob served that the distribution of the intensity of infection, expressed in terms of geometric mean of excreted eggs per gram feces, between sexes in the rural zone was significantly different $\left[D_{\max }\right.$ (0.2498) $D_{5},(0.1972) ; n_{1}=130$ and $n_{2}=75$ ] and this phenomenom did not occur in urban area.

A good correlation was obtained $\left(r_{\mathrm{s}}=0.745\right)$ between the intensity of infection and prevalen ce rate according to the age groups (Figure 3 ) Nevertheless, this correlation was poor $\left(r_{s}=0.196\right)$ between the same parameters in relation to the town and 15 studied areas in Pedro de Toledo.

\section{DISCUSSION}

The overall prevalence rate $(22.8 \%)$ found in Pedro de Toledo in 1980 was considerably higher 
DIAS, L. C. S.: KAWAZOE. U.; GLASSER. C.; HOSHINO.SHIMIZU, S.: KANAMURA, H. Y.: CORDEIRO. J. A.: GUA RITA, O. F. \& ISHIIATA. G. J. - Schistosomiasis mansoni in the municipality of Pedro de Toledo iSảo Paulo. Brazil) where the Biomphalaria tenagophila is the snail host. I - Prevalence in human population. Rev. Inst. Med. trop. São Paulo, 31 (2): 110-118. 1989.

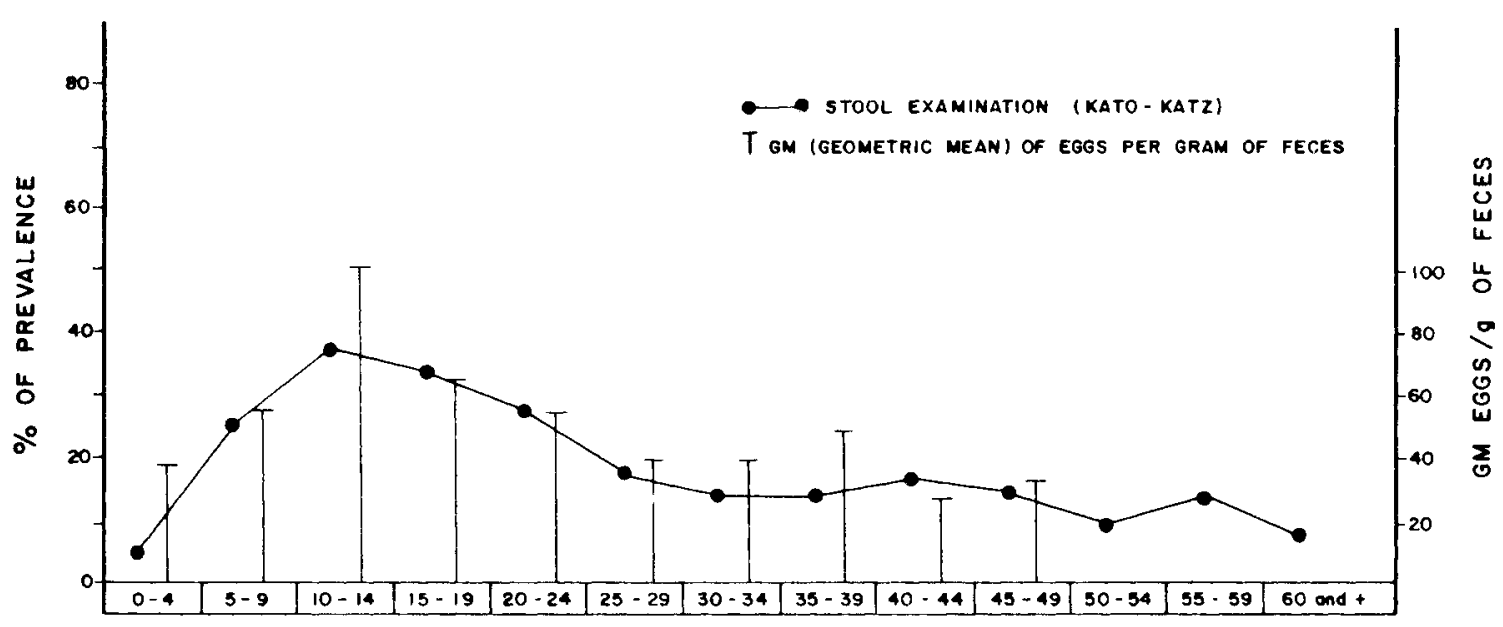

AGE GROUP

Fig. 3 - Prevalence rates of autoch thonous cases of sehistosomiasis mansoni obtained by Kato Katz method and intensity of infection according to age groups, in Pedro de Toledo. Sáo Paulo. Brazil (1980).

than the rate of $12.0 \%$ observed in 1978 when SUCEN performed stool examinations by Kato's qualitative methods in 1,000 inhabitants.

This prevalence is considered high, specially by the fact that, B. tenagophila is known to be an intermediate host of low suceptibility for $\mathbf{S}$. mansoni ${ }^{19.23}$. In that area, from March to $M$ ay of 1980 , only 5 specimens out of 1,137 B. tenagophila collected were realising cercariae of $\mathbf{S}$. mansoni. Those positive snails were collected from two breeding sites, one located in rural and other in urban areas. Since high prevalence rate of schistosomiasis in non-treated cases was de tected in Vila Batista, the causes of high trans mission in that population are now under investigation.

In areas of Brazil where the schistosomiasis is endemic, and where B.glabrata and B.straminea, are considered the intermediate hosts, the human prevalence is usually higher than the one observed in this study ${ }^{16,18}$. The autochthony of endemic cases in Pedro de Toledo is contrary to those found in other regions of Sāo Paulo State, where $88.4 \%$ of the infections are imported and only $10.0 \%$ are autochthonous ${ }^{26}$. It should be emphasized that the transmission of this pa rasitic disease in São Paulo state is found in isolated foci. For instance, the Fazenda Colmeia Focus, in the county of Pindamonhangaba, showed a human prevalence of $17.5 \%$, whereas the rate for the entire Municipality was only $3.3 \%$ Therefore, it is difficult to compare prevalence rates of the endemic diseases in the different regions of the state.

Other helminthiasis reported for Pedro de Toledo showed similar rates to those found in other areas of $\mathrm{Brazil}^{8}$. Although the more specific method for the diagnosis for each parasites not used.

The finding of $73.2 \%$ (Table 1 ) previously treated individuals presented negative egg counts in feces, as well as, the relatively lower intensity of infection associated to a lower prevalence rate in urban area in relation to the rural area $(58.4 \%)$ may be explained by the improvements of the levels of basic sanitation and educa tion received and by other epidemiological factors existing in the region. On the other hand, in rural area which have not receive sanitation improvements the prevalence of schistosomiasis became higher.

The persistence of egg excretions among previously treated subjects appears to be reinfections and probaly development of some drug tolerance or resistence, since the population had been successively submitted to Niridazole, Hycanthone and Oxamniquine treatments. This last aspect is also now under investigation. The prevalence rate of schistosomiasis in Pedro de 
DIAS, L. C. S: KAWAZOE. U; GLASSER, C.: HOSHINO SHIMIZU, S.; KANAMURA, H. Y.: CORDFIRO. J. A.: GUA RITA, O. F. \& ISHIHATA. G. J. - Schistosomiasis mansoni in the municipality of Pedro de Toledo (Sáo Paulo. Brazill where the Biomphalaria tenagophila is the snail host. I - Prevalence in human population. Rev. Inst. Med. trop. Sáo Paulo, 31 (2): 110 118, 1989

Toledo, according to the sex was higher in males than in females (Table 2). This may be explained by the fact that in the studied area, men usually enter water streams more frequently than women. In the Municipality of Roseira (São Paulo State), where the snail host is B. tenagophila, SANTOS ${ }^{24}$ observed that among schoolchildren of the urban area, $90.0 \%$ of infected people were boys. However, in schoolchildren of the lowland area there was no difference related to the sex. In another Municipality vicinity of Roseira, the re was a higher prevalence rate in ales $^{10}$. Howe ver, in Brazilian States where the disease is more endemic, settled for a longer period of time, most investigators agree that there is no significant difference in regard to $\operatorname{sex}^{1.2}$ 2. 4, 18, 22, 24. The frequency distribution of prevalence according to the age groups determined by stool examination, showed an early prime infection $10-4$ age group) in $4.8 \%$ (Figure 1 ). The age group between 5-24 years presented the highest prevalence rate (Figures 1 and 2). This is comparable to the re sults found by others authors in several Brazilian States $^{1,5.13 .14 .17,20}$. In Sāo Paulo State, FROES et $\mathrm{al}^{10}$ found a higher prevalence rate in $10-20$ age group and suggested that the disease in the Municipality of Sào José dos Campos, where the B. tenagophila is the intermediate host, was usually acquired during recreational activities In Pedro de Toledo there was a decrease in the prevalence rates among individuals of 25 years and older (Figures 1 and 2). These data do not agree with the results presented by SANTOS ${ }^{24}$ who reported the highest percentages among ol der individuals working in rice fields and clea ning ditches in the lowland. According to this author, the disease has a professional character. But apparently, this is not the case for Pedro de Toledo, where the schistosomiasis is acquired mainly during recreational activities such as swimming, fishing, etc. In the rural zone, trans mission is also consequence of the use of water for housework.

There is no record of differences between prevalence rates of rural and urban zones in au toch thonous cases (Figure 1 and Table 2 ). In the present area of study there are no clearcut beha vioral boundaries for the inhabitants of both areas although the physical boundaries between the rural and urban zones are well defined. Agri- culture is the main activity of the population: banana is the predominant type of agriculture, followed by vegetables. The mean intensity of infection of $58.5 \mathrm{eggs} / \mathrm{g}$ feces was low to the usu ally found in other Brazilian endemic areas. COU RA \& CONCEIÇÃO ${ }^{6}$ recorded the mean values of 207 and $138 \mathrm{eggs} / \mathrm{g}$ feces respectively in of 1973 and 1974 in a rural community, in the State of Minas Gerais, where the B. glabrata is the major vector. In Pedro de Toledo, the highest intensity rate was observed more in the rural than in the urban area. Male individuals presented a higher number of eggs in the feces than women.

This indicatives that the men of the rural zone have greater contact with the foci of infec. tion. In regard to age groups (Figure 2) the hi ghest intensity of eggs was found in the groups ranging from 5 to 24 years old. In the subsequent age groups, no further attempt was made to carry out any comparison because of the relatively small size of the sample. An interesting fact is that in the 10-14 age group, women of the rural zone showed a geometric mean of $212 \mathrm{eggs} / \mathrm{g}$ of feces (Figure 2). This value is much higher than the geometric mean of 58.5. It was expected that females would generally show a lower intensity rate of infection than men. However, intensity of infection in men was 61.8 and women $52.3 \mathrm{eggs}$ $\mathrm{g}$ of feces. The high geometric mean found in the 10-14 women group is probably related to the fact that these girls frequently enter water streams to wash clothes or cookware, taking the place of their mothers who usually go to the work in the fields. In spite of an irregular excretion of eggs in the feces, their countings in populational studies should be of some value, consi dering that the mass evaluation offsets the cau ses for error ${ }^{1.3 .14 .15 .27}$. The intensity of infection in previously treated patients was not, described here because is well know that intensity decreased in those patients.

The data here obtained regarding to the existence of positive correlation between the geometric mean of egg counts and the prevalence rate will be of value in determining the conversion factor or of the forecast the intensity and prevalence of the infection through the $\mathrm{Ka}$. to-Katz method. 
DIAS, L. C. S.; KAWAZOE, U ; GLASSER, C; HOSHINO-SHIMIZU, S ; KANAMURA, H. Y.; CORDEIRO, J. A.: GUA RITA, O. F. \& ISHIHATA, G. J. - Schistosomiasis mansoni in the municipality of Pedro de Toledo (Sāo Paulo Brazil) where the Biomphalaria tenagophila is the snail host. I - Prevalence in human population. Rev. Inst. Med. trop. São Paulo, 31 (2): 110-118, 1989.

However, in highly endemic area of schistosomiasis, having B. glabrata as the vector, such correlation was not verified ${ }^{15}$. The results here obtained will offer a base line for similar epidemiological works carried out under the same conditions in other areas.

The sensitivity of Kato-Katz method is known to be high intensity of infections ${ }^{7}$ but as verified in previous studies ${ }^{12}$, the parasitological test is not relible, mainly in areas of low and medium prevalence rates. This fact was observed by DIAS et al. ${ }^{9}$, who had to repeat the parasitological test 4 to 5 times to confirm some positive results provided by serological tests. The exact sensitivity of Kato-Katz method is now beeing estimated in relation to skin test and immunofluorescence test. The preliminar results indicate that its sensitivity is lower than $50.0 \%$.

In spite of the problem presented by the $\mathrm{Ka}$. to-Katz method, as to the degree of the sensitivity, it demonstrated that, in Pedro de Toledo. infection starts before 4 years of age. It was verified that in the areas which transmission of the parasite occurs via $\mathbf{B}$. tenagophila, epidemiolo gical characteristics are not so much different from those of other Brazilian areas in which $\mathbf{B}$. glabrata is the intermediate host. The main difference is related to the intensity of infection, which now is still low in Pedro de Toledo.

It is concluded that:

a) the prevalence rate of schistosomiasis man soni in Pedro de Toledo, as determined by stool examination, was $22.8 \%$. The autochthonous carriers were $80.8 \%$;

b) according to the tests employed, younger people ( 5 to 24 years old) were more affected by the infection and the prevalence was higher in males than females;

c) the prevalence rate in the urban zone was the same as in the rural zone when determined by stool examination in autoch thonous cases:

d) more than $70.0 \%$ previously treated cases presented parasitologically negative;

e) the intensity of infection was low, with a geometric mean of $58.5 \mathrm{eggs} / \mathrm{g}$ of feces; f) transmission of schistosomiasis usually oc curred during leisure time and also during the use of water streams for housework in the rural zone;

g) a positive correlation between intensity of infection and prevalence rates according to the age groups was observed.

\section{RESUMO}

Esquistossomose mansônica no município de Pedro de Toledo (São Paulo, Brasil) onde Biomphalaria tenagophila é hospedeiro intermediário. I - Prevalência na população humana.

Devido à escassez de dados epidemiológicos sobre esquistossomose mansônica onde Biomphalaria tenagophila é vetor foi desenvolvido em 1980 o presente trabalho, no municipio pau lista de Pedro de Toledo. Foram examinadas fe zes de 4741 pessoas (Método de Kato-Katz) com prevalência de $22,8 \%$; entre essas, 583 foram tra tadas para a endemia anteriormente e 4158 não medicadas; as prevalências nos dois grupos foram, respectivamente, $31,7 \%$ e $21,6 \%$. Por investigaçāo epidemiologica constatou-se que $83,6 \%$ dos casos foram autóctones da área estudada. Prevalència dos autóctones e intensidade de infecçāo nos portadores autóctones não tratados foram maiores no homem do que na mulher: a intensidade no último grupo foi baixa: 58,5 ovos/ $g$ de fezes (média geométrica). De acordo com grupos etários, se correlacionaram bem $\left(\mathbf{r}_{\mathrm{s}}=\right.$ 0,745 ) as intensidades de infecção e as preva lências. A infecção ocorreu, na zona rural, principalmente, durante lazer e trabalho doméstico. Somente $0,4 \%$ de 1137 moluscos foram positivos para Schistosoma mansoni. Esse indice foi, aparentemente, o mesmo em estudo de 1978 quando a prevalência humana era de $12,0 \%$. A área estu dada apresentou diferenças e semelhanças epi demiológicas em relação às áreas onde $\mathbf{B}$. glabrata é o principal hospedeiro intermediário.

\section{ACKNOWLEDGEMENTS}

To Dr. Antonio Guilherme de Souza for support given throughout all stages of the study; to Drs. A. E. Piedrabuena and L. K. Hotta for help with the statistical analysis; to Prof. Dr. 
DIAS. L. C. S.: KAWAZOE, U G GLASSER. C.: HOSHINO SHIMIZU, S.: KANAMURA, H. Y .: CORDEIRO, J. A.: GUA RITA. O. F. \& ISHIIATA G J. - Schistosomiasis mansoni in the municipality of Pedro de Toledo isao Paulo Brazil) where the Biomphalaria tenagophila is the snail host. I - Prevalence in human population. Rev. Inst. Med. trop. São Paulo, $31(2): 110118,1989$

Luiz Caetano da Silva for suggestions in writting the text; to Mrs. Rosa Maria de Jesus Patucci and other SUCEN collaborators for valuable help in the field work; to Mr. Luiz Henrique Allt

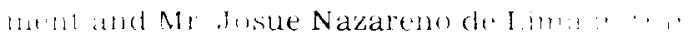
cribing data.

\section{REFERENCES}

1. BARBOSA, F A S - Morbidade da esquistossomose Rev. bras. Malar.. (n: esp.1: 3159.1966

2. BARBOSA, F. S. - Epidemiologia. In: CUNHA. A. S. da - Esquístossomose mansoni. Sao Paulo. Editora da Uni versidade de Sāo Paulo, 1970. p. 31.59

3. BARTHOLOMEW, R. K : PETERS, P.A. S. \& JORDAN, P. -- Schistosoma mansoni in St. Lucian and Kenyan com munities - a comparative study using the Kato stool exa mination technique. Ann. trop. Med. Parasit., 75: 401405, 1981

4. BRENER, Z, \& MOURÁ, O, G. -.- Inquerito clínico-epi demiológico em focos endêmicos de esquistossomose em Minas Gerais. Rev. bras. Malar., 28: 1.43.154, 1952.

5. CONCEICAOO M J PEDROSA P N SILVA J N S da \& COURA, J. R. - Estudo piloto sobre esquistosso mose mansoni em área rurali do municipio de Itanhomi Vale do Rio Doce, Minas Gerais. Rev. Soc. bras. Med. trop. 12. 8186,1978

6. COURA J.R. \& CONCEICÁO. M. J.. Correlaça entre carga parasitária de Schistosoma mansoni e gravidade das formas ciinicas em uma comunidade rural de Minas Gerais. Rev. Soc. bras. Med. trop., 14: 9397,1981

7. COSTA.M.F.L.:ROCHA.R.S. \& KATZ.N. - Morbidade da esquistossomose e sua relaçāo com contagem de Schistosoma mansoni em uma zona hiperendemica do Estado de Minas Gerais Rev. Inst. Med. trop. S. Paulo, 27:6675 1985 .

8. DIAS, L. C S.-Geohelmintiasis en Brasil. Bol.chil. Parasit., 36: 2728,1981 .

9. DIAS. L.C.S.: CAMARGO. M. E.:HOSHINO.S.: RAMOS A. S.: PIZA. J. T. \& SILVA. L. C. da-Inqueritos popula cionais da esquistossomose mansoni por tecnicas sorolo gicas de imunofluorescéncia e de hemaglutinaçāo. Rev Inst. Med. trop. S. Paulo, 13: 37-44. 197

10. FROES, E.; PIZA, J. T.; RAMOS, A. S.; DIAS, L. C. S \& PINTO, A. C. M. -... Aspectos da epidemiologia e profi laxia da esquistossomose mansoni em Săo José dos Cam. pos. Hospital (Rio de J.). 7 7: 153 164, 1970

11. KATZ, N.: COELHO, P. M. Z. \& PELLEGRINO, J. A A simple device of quantitative stool thick-smear technique in schistosomiasis mansoni. Rev. Inst. Med. trop. S. Paulo, 14: 397400,1972 .

12. KAWAZOE. U.: HOSHINO-SHIMIZU, S.: CORREA. N S.: SILVA, L. C. da: PINTO, A. C. M. \& CAMARGO, M E. - An immunoepidemiological study of Schistosoma mansoni in Paraiba's Valley, Sảo Paulo, Brazil. Rev. Inst. Med. trop. S. Paulo, 23: 36-40, 1981 .
13. KLOETZEL $K$ - - Algumas observaçoes de epidemiologia da esquistossomose na infancia. Mospital (Rio de J.), 55: 661669,1959

14. KLOETZEL. K. - Aspectos epidemiologicos da esquistossomose mansonica em uma populacáo de Pernambuco. Sào Paulo. 1962. ITøse de doutoramento-Faculdade de Medicina da Universidade de Sào Paulol

15. LEHMAN Jr.. J. S.: MOTT, K. E.: MORROW Jr., R. H MUNIZ, T. M. \& BOYER, M. H. - The intensity and effects of infections with Schistosoma mansoni in rural commu nity in northeast Brazil. Amer. J. trop. Med. Hyg.. 25: 285294,1976

16. MACHADO, P A. - The Brazilian program for schistoso miasis control, 1975 1979 Amer. J. trop. Med. Hyg., 31: $76-86,1982$

17. MARTINS. A. V. \& VERSIANI.W. - Schistosomose man soni no Norte de Minas Gerais. Brasil-méd., 52: $812-816$. 1938 .

18. MENEZES, A. P. de \& COURA. J. R. - Estudo seccional sobre esquistossomose mansonica no municipio de Ria chuelo, Estado de Sergipe. Rev. Soc. bras. Med. trop., 13: 1 $15.1979: 1980$

19. PARAENSE, W. L. \& CORREA, L. R. - Susceptibility of Australorbis tenagophilus to infection with Schistosoma mansoni. Rev. Inst. Med. trop. S. Paulo, 5: 2329. 1963

20. PESSOA S. B \& AMORIM. J. P. - Notas sobre a esquis tossomose mansonica em algumas localidades de Ala goas. Rev. bras. Med., 14: $420422,1957$.

21. PIZA. J. T. \& RAMOS. A. S. - Os focos autoctones de esquistossomose no Estado de Sāo Paulo. Arq. Hig. is. Paulo), 25: 261 271. 1960 .

22. PRATA. A. -... Esquistossomose mansonica. In: VERO NESI. R. -- Doenças infecciosas e parasitarias. 4 ed Rio de Janeiro, Guanabara Koogan, 1969 p. 852873

23. SANTANA, J. V; MAGALHAES. L. A. \& RANGEL, H. A. - Seleço de linhagens de Biomphalaria tenagophila e Biomphalaria glabrata visando maior susceptibilidade an Schistosoma mansoni. Rev. Saude públ. (S. Paulo), 12: 6777.1978

24. SANTOS, N.R. doS-Esquistossomose mansónica autoctone no Vale do Medio Paraiba, Estado de São Paulo. Brasil, Contribuiça para o estudo de zona endemica. Sáo Paulo, 1967. (Tese de doutoramen to - Faculdade de Medicina da Universidade de Sāo Paulo

25. SIEGEL, S. - Nonparametric statistics for the behavioral sciences. New York. Mc Graw-Hill. 1956

26. SUPERINTENDÉNCIA DE CONTROLE DE ENDEMIAS (SUCEN) - Situaçảo da esquistossomose no Estado de Sào Paulo (Relatórios. Sào Paulo, Imprensa Oficial do Es tado. Secretaria de Estado da Saude. 1982.

27. WEBBE, G. \& JORDAN. P. - Recent advances in know ledge of sehistosomiasis in East Africa. Trans. roy. Soc. trop. Med. Hyg., 60: 279-306, 1966.

Recebido para publicacảo em 14/11:1988 